\title{
CONCRETE PAVEMENT LAYER MODULI BASED ON STABLE DEFLECTION
}

\author{
Lijun SUN ${ }^{1}$, Yoshitaka HACHIYA ${ }^{2}$ and Zukang YAO $^{3}$ \\ ${ }^{1}$ Dr. of Eng., Professor, Dept. of Road \& Traffic Eng., Tongji University \\ (1239 Siping Road, Shanghai 200092, China) \\ ${ }^{2}$ Member of JSCE, Dr. of Eng., Chief, Runways Lab., Port and Harbor Research Institute, Ministry of Transport \\ (1-1, Nagase 3, Yokosuka 239, Japan) \\ ${ }^{3}$ Professor, Dept. of Road \& Traffic Engineering, Tongji University
}

\begin{abstract}
Microcomputer methods are widely used to backcalculate pavement layer moduli from deflections measured on the pavement surface. To increase the precision of the backcalculated moduli, a new, layer moduli backcalculation method based on the stable deflection was developed for concrete pavements. This stable deflection is defined as being independent of the slab modulus. Thus, it is a critical parameter for uniquely determining the foundation reaction modulus and for further backcalculating the slab modulus.

This procedure was used to evaluate the structural condition of concrete pavement in a working airport, and the usefulness of the method was verified as a result.
\end{abstract}

Key Words: concrete pavement, structural evaluation, stable deflection, FWD, backcalculation, layer modulus

\section{INTRODUCTION}

Nondestructive testing (NDT) has become widely accepted as an increasingly cost-effective tool for evaluating the structural condition of airport and highway pavements and is now an interesting and active research area in the world. Estimations of the pavement layer moduli from deflections measured by NDT is a major problem, and numerous backcalculation methods have been developed. These backcalculation methods are divided into four categories, ${ }^{1)}$ i.e.,

(a) traditional methods based on graphs and/or tables,

(b) microcomputer methods, such as ELCON, ILLI-

BACK for rigid pavements, and ISSEM4, MODCOM3, MODULUS and WESDEF for flexible pavements,

(c) system identification methods, and

(d) impulse methods for near-field measurements.

Of these, microcomputer methods are discussed here. In fact, the basic principles used in the various layer moduli backcalculation methods are similar; i.e., they attempt to find a set of moduli that minimize the difference between the measured deflection basin shape and the shape calculated using known layer moduli. The typical objective function used in moduli backcalculation is as follows: ${ }^{2)}$

$$
\operatorname{Min} e^{2}=\sum_{i=1}^{N}\left(D_{M_{i}}-D_{C_{i}}\right)^{2}
$$

where,

$D_{M i}, D_{c i}:$ the measured and calculated deflection at $i$ th sensor, respectively, and

$N \quad$ : the total number of sensors.

Because the layer moduli significantly influence the shape of the deflection basin, the set of moduli obtained through Eq. (1) is usually not unique. This often results in greater errors in the backcalculated moduli. ${ }^{1)}$

Many refined algorithms have been developed to improve the uniqueness of the solution and to increase the precision of the backcalculated moduli. Two methods are typical, i.e. the use of different weighting factors for the various sensors, and the use of a range of moduli for each pavement material.

Thus, the layer moduli backcalculation process becomes the following optimization process with the constraint of layer moduli: 


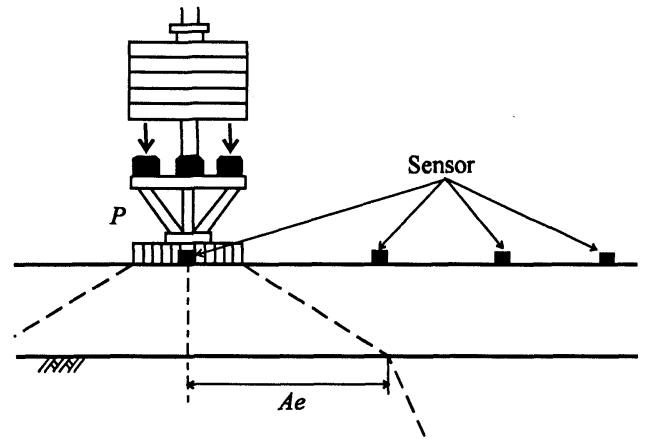

Fig. 1 Stress zone in pavement structure

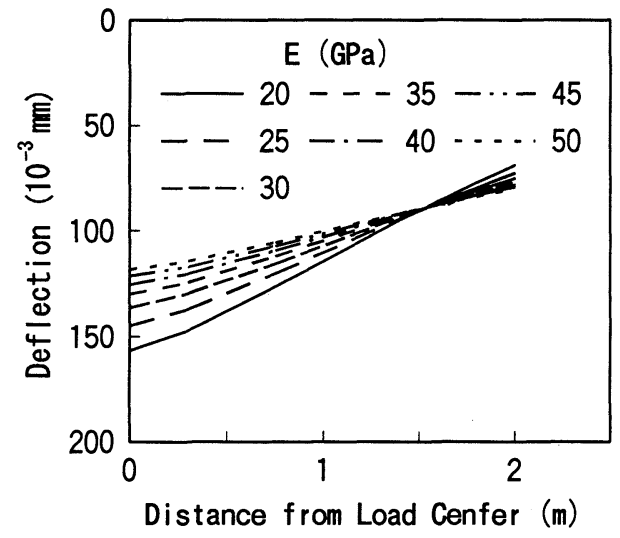

Fig. 2 Stable deflection within a narrow range

where,

$$
\begin{aligned}
& \operatorname{Min} e^{2}=\sum_{i=1}^{N} W_{i} \cdot\left(D_{M_{i}}-D_{C_{i}}\right)^{2} \\
& E_{j} \leq E_{j \max } \\
& E_{j} \geq E_{j \min }
\end{aligned}
$$

$W_{i} \quad$ : a weighting factor of $i$ th sensor,

$E_{j}, E_{j \min }, E_{j \max }$ : backcaltulated, possible minimum and maximum modulus of $j$ th layer, respectively.

Even with these techniques, moduli backcalculation is still a laborious process that requires a high degree of skill. The results are known to be highly dependent on the individuals doing the backcalculation. ${ }^{3)}$

This paper presents a new, layer moduli backcalculation method for concrete pavement that is based on a stable deflection. The structural condition of concrete pavement in a working airport is then evaluated.

\section{FEATURES OF CONCRETE PAVEMENT DEFLECTION BASINS}

The effect of a pavement layer under load is shown in Fig. 1. The load applied to the surface is distributed through the thickness of the pavement system. The stress distribution in the pavement is clearly related to the layer moduli, i.e. the stress distribution area increases with increasing modulus. Surface deflections obtained at or beyond the distance $A e$ in the figure are due only to stresses, and hence deformations, within the foundation itself, while surface deflections near the load are mainly dependent on the surface modulus.

The deflection basins of concrete pavement, including deflections far away from the load, are dependent on both the slab (elastic) modulus and the foundation reaction modulus. That is, the smaller the foundation reaction modulus is, the greater the deflections will be both at the load center and at points away from the load. A higher slab modulus produces a flatter deflection basin; i.e., the deflections near load center are relatively small, while the deflections far away from the load are relatively large. Conversely, a lower slab modulus results in a deeper deflection basin; i.e., the deflections near load center are relatively large, while the deflections far away from the load are relatively small. Thus, an intersection between deflection basin shapes with high and low slab moduli must exist at which the deflection is independent of slab modulus, as shown Fig. 2.

In order to prove the existence of the point at which the pavement deflection is independent of slab modulus, the authors used the thick plate theory to analyze numerous deflection basins of concrete pavement structures. As shown in the example given in Fig. 2, the deflections at a particular radius (about $1.55 \mathrm{~m}$ from the load center) are almost unchanged. The deflection basins intersect within a narrow range that is less than $50 \mathrm{~mm}$ wide even for different slab moduli. In other words, a relatively stable point exists on the deflection basin at which the deflection remains nearly unchanged for varying slab moduli. The deflection at any other point is dependent on both the slab modulus and the foundation reaction modulus. Thus, a deflection that is independent of the slab modulus is critical for uniquely determining the foundation reaction modulus and further backcalculating the slab modulus. This deflection is defined as the stable deflection $D c$ at the distance from the load center $R c$. 
Table 1 Concrete pavement parameters used in deflection analysis

\begin{tabular}{l|l}
\hline Slab Thickness (mm) & $200,250,300,350,400,450$ \\
Slab Modulus (GPa) & $20,25,30,35,40,45,50$ \\
Foundation Reaction Modulus & $50,100,150,200$ \\
$(\mathrm{MPa} / \mathrm{m})$ & \\
Slab Dimension (m) & $4 \times 4,5 \times 5,7.5 \times 7.5$ \\
Load Plate Diameter (mm) & 300,450 \\
\hline
\end{tabular}

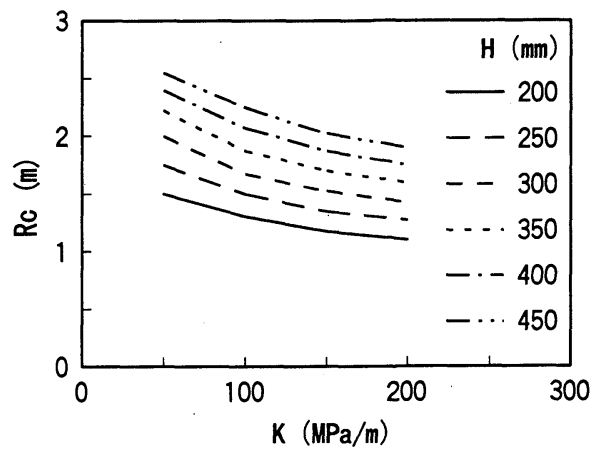

Fig. 3 Relationship between $K, H$, and $R c$

Table 2 Calculated $R c$ and $D c$

\begin{tabular}{c|c|c|c|c|c|c|c}
\hline $\begin{array}{c}H \\
(\mathrm{~mm})\end{array}$ & $\begin{array}{c}K \\
(\mathrm{MPa} / \mathrm{m})\end{array}$ & \multicolumn{2}{|c|}{$4 \mathrm{~m} \times 4 \mathrm{~m}$ Slab } & \multicolumn{2}{c|}{$5 \mathrm{~m} \times 5 \mathrm{~m} \mathrm{Slab}$} & \multicolumn{2}{c}{$7.5 \mathrm{~m} \times 7.5 \mathrm{~m} \mathrm{Slab}$} \\
\cline { 3 - 8 } & & $\begin{array}{c}R c \\
(\mathrm{~m})\end{array}$ & $\begin{array}{c}D c \\
\left(10^{-3} \mathrm{~mm}\right)\end{array}$ & $\begin{array}{c}R c \\
(\mathrm{~m})\end{array}$ & $\begin{array}{c}D c \\
\left(10^{-3} \mathrm{~mm}\right)\end{array}$ & $\begin{array}{c}R c \\
(\mathrm{~m})\end{array}$ & $\begin{array}{c}D c \\
\left(10^{-3} \mathrm{~mm}\right)\end{array}$ \\
\hline 200 & 50 & 1.375 & 104.92 & 1.475 & 90.27 & 1.500 & 182.64 \\
& 100 & 1.225 & 65.45 & 1.225 & 63.49 & 1.300 & 120.50 \\
& 150 & 1.125 & 51.25 & 1.125 & 49.29 & 1.175 & 97.91 \\
& 200 & 1.025 & 45.58 & 1.050 & 41.82 & 1.100 & 83.53 \\
\hline 250 & 50 & 1.475 & 93.07 & 1.675 & 70.46 & 1.750 & 138.94 \\
& 100 & 1.375 & 52.27 & 1.475 & 44.93 & 1.500 & 91.77 \\
& 150 & 1.275 & 40.91 & 1.325 & 36.58 & 1.350 & 74.46 \\
& 200 & 1.200 & 33.84 & 1.225 & 31.56 & 1.275 & 62.34 \\
\hline 300 & 50 & 1.500 & 90.91 & 1.775 & 63.21 & 2.000 & 108.97 \\
& 100 & 1.450 & 47.58 & 1.625 & 37.20 & 1.675 & 74.95 \\
& 150 & 1.400 & 28.81 & 1.500 & 28.90 & 1.525 & 59.18 \\
& 200 & 1.350 & 26.89 & 1.400 & 24.67 & 1.425 & 50.28 \\
\hline 350 & 50 & 1.525 & 88.32 & 1.850 & 59.20 & 2.225 & 89.17 \\
& 100 & 1.500 & 45.37 & 1.725 & 33.13 & 1.875 & 61.07 \\
& 150 & 1.450 & 31.62 & 1.625 & 24.70 & 1.700 & 48.50 \\
& 200 & 1.425 & 24.36 & 1.550 & 20.26 & 1.600 & 40.52 \\
\hline 400 & 50 & 1.550 & 88.42 & 1.900 & 57.34 & 2.400 & 76.87 \\
& 100 & 1.525 & 45.65 & 1.800 & 30.37 & 2.075 & 50.64 \\
& 150 & 1.500 & 30.17 & 1.725 & 22.01 & 1.875 & 41.56 \\
& 200 & 1.475 & 23.07 & 1.675 & 17.41 & 1.750 & 34.41 \\
\hline 450 & 50 & 1.550 & 88.42 & 1.925 & 56.72 & 2.550 & 68.33 \\
& 100 & 1.525 & 44.58 & 1.850 & 29.49 & 2.250 & 43.38 \\
& 150 & 1.500 & - & 1.800 & 20.43 & 2.025 & 35.62 \\
& 200 & 1.475 & 23.02 & 1.750 & 16.03 & 1.900 & 29.61 \\
\hline
\end{tabular}

Load Diameter. $300 \mathrm{~mm}$ for $4 \times 4$ and $5 \times 5$ Slab, and $450 \mathrm{~mm}$ for $7.5 \times 7.5 \mathrm{Slab}$ Load Intensity: $1 \mathrm{Mpa}$

\section{ANALYSIS OF STABLE DEFLECTION}

The position $(R c)$ and magnitude $(D c)$ of the stable deflection are useful in layer moduli backcalculation. The authors consider the slab modulus and the foundation reaction modulus as the dominant parameters and addressed deflection basins at the slab center, although many factors have a significant influence.

\section{(1) Analysis Condition}

Considering both pavement structures and material characteristics commonly used in airport and highway construction, the deflection basins were analyzed for concrete pavements having the various structural parameters shown in Table 1. The deflection basins with all combinations of the parameters shown in this table were obtained by calculating the deflection at $50 \mathrm{~mm}$ intervals.

\section{(2) Position of Stable Deflection}

The practical determination of the stable deflection used the point where the change of deflections is within $1.5 \%$ for slab moduli of 20 and $50 \mathrm{GPa}$. Based on this principle, $R c$ is determined from the deflection basin data, as listed in Table 2. 
Table 3 Range of $R c$

\begin{tabular}{l|c|c|c|c|c|c}
\hline \multirow{2}{*}{$\begin{array}{l}\text { Slab Dimension } \\
(\mathrm{m} \times \mathrm{m})\end{array}$} & \multicolumn{6}{|c}{ Slab Thickness (mm) } \\
\cline { 2 - 7 } & 200 & 250 & 300 & 350 & 400 & 450 \\
\hline $4 \times 4$ & $1.00-1.40$ & $1.20-1.50$ & $1.30-1.50$ & $1.40-1.55$ & $1.45-1.55$ & $1.45-1.55$ \\
$5 \times 5$ & $1.05-1.50$ & $1.20-1.70$ & $1.40-1.80$ & $1.50-1.90$ & $1.65-1.90$ & $1.75-1.95$ \\
$7.5 \times 7.5$ & $1.10-1.50$ & $1.25-1.75$ & $1.40-2.05$ & $1.60-2.25$ & $1.75-2.40$ & $1.90-2.55$ \\
\hline
\end{tabular}

(unit: m)

Table 4 Coefficients in Eq. (3)

\begin{tabular}{c|r|r|r}
\hline Coefficient & \multicolumn{1}{|c|}{4 x 4 Slab } & \multicolumn{1}{c|}{$5 \times 5$ Slab } & $7.5 \times 7.5$ Slab \\
\hline $\mathrm{a}_{0}$ & $2.0565 \mathrm{E}-01$ & $-5.2959 \mathrm{E}+00$ & $1.5264 \mathrm{E}+00$ \\
$\mathrm{a}_{1}$ & $1.5687 \mathrm{E}-02$ & $7.8658 \mathrm{E}-02$ & $-7.8229 \mathrm{E}-03$ \\
$\mathrm{a}_{2}$ & $-6.9500 \mathrm{E}-05$ & $-3.2357 \mathrm{E}-04$ & $6.3783 \mathrm{E}-05$ \\
$\mathrm{a}_{3}$ & $1.3790 \mathrm{E}-07$ & $5.9435 \mathrm{E}-07$ & $-1.2706 \mathrm{E}-07$ \\
$\mathrm{a}_{4}$ & $-1.0200 \mathrm{E}-10$ & $-4.0867 \mathrm{E}-10$ & $8.3667 \mathrm{E}-11$ \\
\hline $\mathrm{b}_{0}$ & $-6.5407 \mathrm{E}-03$ & $-3.7467 \mathrm{E}-03$ & $-8.0339 \mathrm{E}-03$ \\
$\mathrm{~b}_{1}$ & $2.9800 \mathrm{E}-05$ & $7.0798 \mathrm{E}-06$ & $8.4677 \mathrm{E}-05$ \\
$\mathrm{~b}_{2}$ & $-3.5614 \mathrm{E}-08$ & & $-4.3134 \mathrm{E}-07$ \\
$\mathrm{~b}_{3}$ & & & $9.2118 \mathrm{E}-10$ \\
$\mathrm{~b}_{4}$ & & & $-6.9953 \mathrm{E}-13$ \\
\hline
\end{tabular}

As can be seen from Fig. 3, which was plotted using data for a $7.5 \mathrm{~m} \times 7.5 \mathrm{~m}$ slab, $R c$ decreases with increasing foundation reaction modulus and increases with increasing slab thickness. The range of $R c$ for various pavement structural parameters is listed in Table 3.

The relationships between $R c(\mathrm{~m})$, the foundation reaction modulus $K(\mathrm{MPa} / \mathrm{m})$ and the slab thickness $H(\mathrm{~mm})$ can be regressed using the data in Table 2 as follows:

$$
\begin{aligned}
& R c=A \cdot \exp (B \cdot K) \\
& A=a_{0}+a_{1} \cdot H+a_{2} \cdot H^{2}+a_{3} \cdot H^{3}+a_{4} \cdot H^{4} \\
& B=b_{0}+b_{1} \cdot H+b_{2} \cdot H^{2}+b_{3} \cdot H^{3}+b_{4} \cdot H^{4}
\end{aligned}
$$

Coefficients $a_{0}$ through $a_{4}$ and $b_{0}$ through $b_{4}$ are shown in Table 4.

\section{(3) Stable Deflection}

Although the stable deflection is nearly independent of the slab modulus, it decreases with increases in either $K$ or $H$. This is shown in Fig. 4, which was plotted using data for the $7.5 \mathrm{~m} \times 7.5 \mathrm{~m}$ slab. The following relationships were obtained based on these data ( $P$ denotes the load in $\mathrm{N})$ :

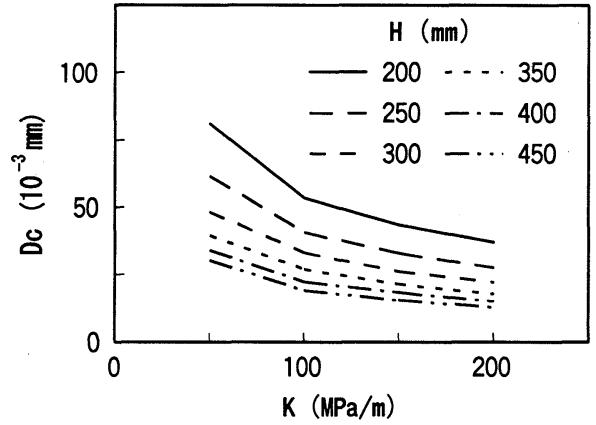

Fig. 4 Relationship between $K, H$, and $D c$

Table 5 Coefficients in Eq. (4)

\begin{tabular}{c|r|r|r}
\hline Coefficient & \multicolumn{1}{c|}{4 x 4 Slab } & \multicolumn{1}{c|}{$5 \times$ x Slab } & $7.5 \times 7.5$ Slab \\
\hline $\mathrm{c}_{0}$ & $2.7716 \mathrm{E}-03$ & $3.3377 \mathrm{E}-02$ & \\
$\mathrm{c}_{1}$ & $-8.5124 \mathrm{E}-06$ & $-3.5470 \mathrm{E}-04$ & \\
$\mathrm{c}_{2}$ & $9.8472 \mathrm{E}-08$ & $1.4856 \mathrm{E}-06$ & \\
$\mathrm{c}_{3}$ & $-1.4023 \mathrm{E}-10$ & $-2.6930 \mathrm{E}-09$ & \\
$\mathrm{c}_{4}$ & & $1.8128 \mathrm{E}-12$ & \\
\hline $\mathrm{d}_{0}$ & $4.5680 \mathrm{E}-01$ & $-1.4966 \mathrm{E}+00$ & $-9.4451 \mathrm{E}-01$ \\
$\mathrm{~d}_{1}$ & $-7.0327 \mathrm{E}-03$ & $1.1075 \mathrm{E}-02$ & $5.0817 \mathrm{E}-03$ \\
$\mathrm{~d}_{2}$ & $8.5987 \mathrm{E}-06$ & $-3.9871 \mathrm{E}-05$ & $-2.5058 \mathrm{E}-05$ \\
$\mathrm{~d}_{3}$ & & $4.0313 \mathrm{E}-08$ & $5.5122 \mathrm{E}-08$ \\
$\mathrm{~d}_{4}$ & & & $-4.6100 \mathrm{E}-11$ \\
\hline
\end{tabular}

$$
\begin{aligned}
& D c=P \cdot C \cdot(K / 9.80665)^{D} \\
& C=c_{0}+c_{1} \cdot H+c_{2} \cdot H^{2}+c_{3} \cdot H^{3}+c_{4} \cdot H^{4} \\
& D=d_{0}+d_{1} \cdot H+d_{2} \cdot H^{2}+d_{3} \cdot H^{3}+d_{4} \cdot H^{4}
\end{aligned}
$$

Coefficients $c_{0}$ through $c_{4}$ and $d_{0}$ through $d_{4}$ are shown in Table 5. For $7.5 \mathrm{~m} \mathrm{x} 7.5 \mathrm{~m}$ slab, $C$ is expressed as $C=0.0016955 H^{-1.1837}$. 
Because the slab thickness is known when backcalculating the layer moduli, $D c$ is only dependent on the foundation reaction modulus. Therefore, $K$ can be uniquely determined after $D c$ is determined by backcalculating from the measured deflection basin. The slab modulus can then be backcalculated using any deflection, such as the one at the load center.

\section{BACKCALCULATION PROCEDURE FOR LAYER MODULI OF CONCRETE PAVEMENT}

\section{(1) Determination of $K$}

A trial and error procedure is used to determine the foundation reaction modulus $K$. An example is given below.

In order to simplify the example, Fig. 5 is also plotted using the data in Figs. 3 and 4. An example of the deflection basin for a concrete pavement with a slab of $7.5 \mathrm{~m}$ by $7.5 \mathrm{~m}$ by $350 \mathrm{~mm}$ thick is listed in Table 6.

From Table 3, the stable deflection $(R c)$ is assumed to be located between 1.6 and $2.25 \mathrm{~m}$. Therefore,

Step 1: Assume $1.9 \mathrm{~m}$ as $R c$ ( $\left.=R c^{\prime}\right)$,

Step 2: Interpolate $D c$ at $R c^{\prime}$ based on measured deflection in Table 6,

Step 3: Calculate $R c$ from Fig. 5 based on $D c$,

Step 4: Calculate difference between $R c$ and $R c^{\prime}$. If the difference is not sufficiently small, go to Step 5, otherwise go to Step 6,

Step 5: Let $R c^{\prime}=R c$, and go to Step 2, and

Step 6: Calculate $K$ based on $R c$.

In this example, the calculated $K$ is $96.1 \mathrm{MPa} / \mathrm{m}$. Because the slab dimensions, slab thickness and $K$ are given, $R c$ and $D c$ are unique. Therefore, the converged foundation reaction modulus is also unique.

\section{(2) Flowchart for Layer Moduli Backcalculation}

Two steps are included in the layer moduli backcalculation for concrete pavement, i.e. the determination of the foundation reaction modulus and the backcalculation of the slab modulus, as shown in Fig. 6.

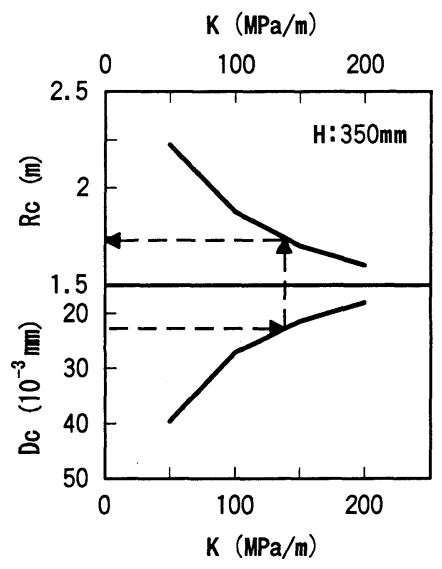

Fig. 5 Determination procedure of $K$

Table 6 Example of concrete pavement deflection basin

\begin{tabular}{l|c|c|c|c|c|c|c}
\hline Sensor No. & 1 & 2 & 3 & 4 & 5 & 6 & 7 \\
\hline $\begin{array}{l}\text { Distance from } \\
\text { Load Center }(\mathrm{mm})\end{array}$ & 0 & 300 & 450 & 600 & 900 & 1500 & 2500 \\
\hline Deflection $\left(10^{-3} \mathrm{~mm}\right)$ & 241 & 225 & 209 & 194 & 166 & 95 & 45 \\
\hline
\end{tabular}

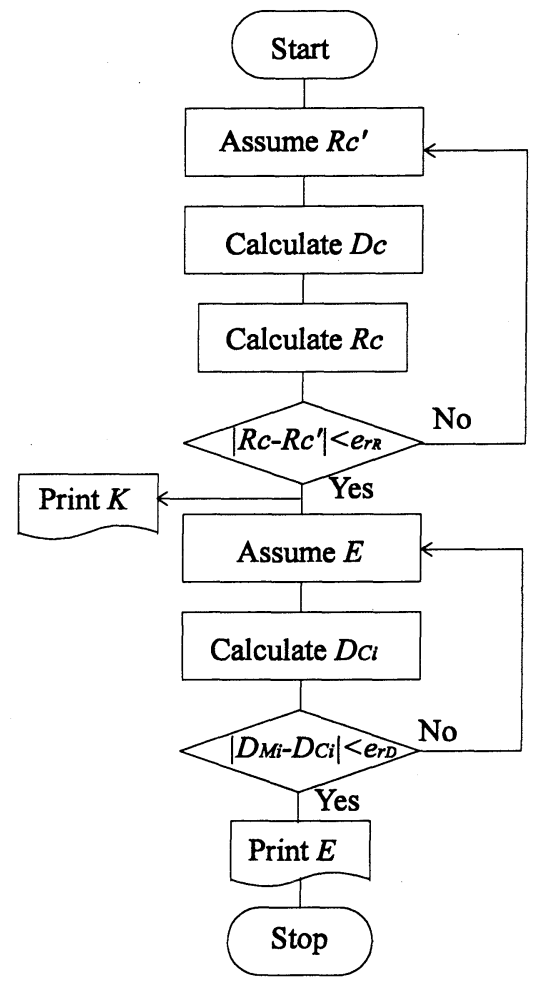

Fig. 6 Flowchart of layer moduli backcalculation 


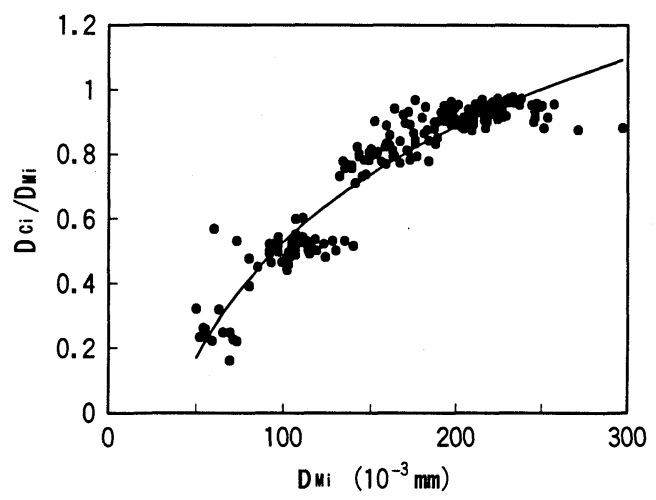

Fig. 7 Adjustment factor for FWD deflections

\section{APPLICATION TO ACTUAL AIRPORT CONCRETE PAVEMENT}

\section{(1) Outline}

The airport concrete pavement analyzed in this paper was constructed about 5 years ago and includes two pavement structures, i.e., one with dimensions of $7.5 \mathrm{~m}$ by $7.5 \mathrm{~m}$ by $350 \mathrm{~mm}$ thick, and another with dimensions of $5 \mathrm{~m}$ by $5 \mathrm{~m}$ by $200 \mathrm{~mm}$ thick. The foundation reaction modulus used in the design was $70 \mathrm{MPa} / \mathrm{m}$, and the slab modulus used in design was $35 \mathrm{GPa}$. The FWD tests were made in June 1994.

\section{(2) Data Adjustment}

A comparison between the calculated and measured deflection basins shows significant differences, where the measured deflection basins are much flatter than the calculated ones. This may be caused by assuming the subgrade acts as a Winkler foundation when calculating the deflection basin. The foundation reaction modulus, however, should be obtained from the concrete pavement evaluation because this foundation model was used in the concrete pavement structural design.

The authors attempted to adjust the measured data to make use of this procedure and to determine the possible stable deflection points from the measured deflection basin data. Using the possible stable deflection points shown in Table 2, the following data adjustment factor was obtained, as shown in Fig. 7.

$$
\begin{aligned}
C F & =D_{C i} / D_{M i} \\
& =-1.901+1.191 \cdot \log \left(D_{M i}\right)
\end{aligned}
$$

where,

$i \quad:$ sensor No. $(=3,4, \ldots, 7)$,
Table 7 Adjustment of measured deflection basin

\begin{tabular}{l|c|c|c|c|c|c|c}
\hline Sensor No. & 1 & 2 & 3 & 4 & 5 & 6 & 7 \\
\hline $\begin{array}{l}\text { Measured Deflection } \\
\left(10^{-3} \mathrm{~mm}\right)\end{array}$ & 285 & 273 & 268 & 256 & 229 & 190 & 135 \\
\hline $\begin{array}{l}\text { Adjusted Deflection } \\
\left(10^{-3} \mathrm{~mm}\right)\end{array}$ & 285 & 273 & 268 & 256 & 219 & 163 & 92 \\
\hline
\end{tabular}

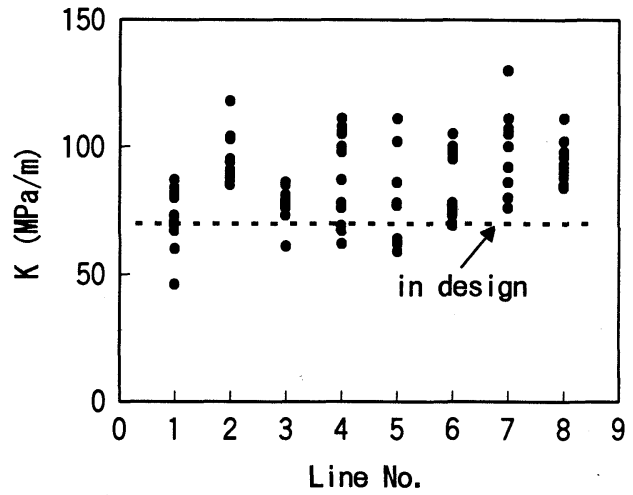

Fig. 8 Comparison between backcalculated $K$ and $K$ used in design

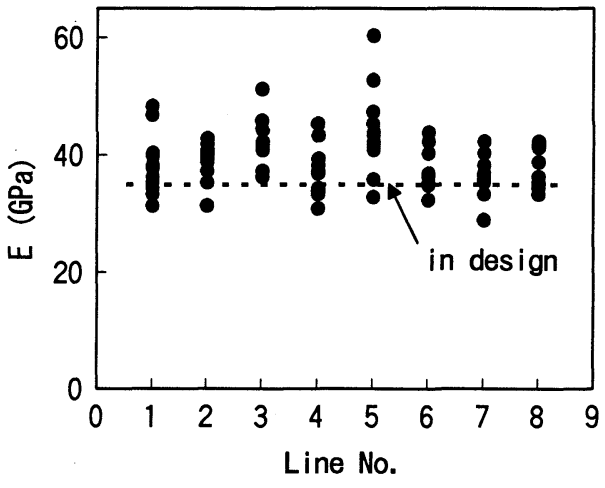

Fig. 9 Comparison between backcalculated $E c$ and $E c$ used in design

$D_{c i}, D_{m i}$ : calculated, measured deflection in $1 / 1000$ $\mathrm{mm}$, respectively.

If $C F$ calculated from Eq. (5) is larger than unity, then let $C F=1$.

Before backcalculating the concrete pavement layer moduli, the measured deflection basin should be adjusted using Eq. (5) as shown in Table 7. 


\section{(3) Backcalculated Layer Moduli}

The backcalculated moduli are described in Figs. 8 and 9, which compare the backcalculated modulus with that used in the design. Obtained moduli coincide well with those used in the design.

\section{CONCLUDING REMARKS}

Although numerous layer moduli backcalculation methods have been developed for airport and highway concrete pavement, the range of backcalculated moduli is still large. A stable deflection was found in concrete pavements, and based on the new findings, a new, layer moduli backcalculation method was developed for the nondestructive evaluation of concrete pavements. This was used for the nondestructive evaluation of a working airport concrete pavement, and the estimated slab modulus and the foundation reaction modulus were comparable to those used in the design.

For the nondestructive tests made in a concrete pavement with dimensions of $7.5 \mathrm{~m}$ by $7.5 \mathrm{~m}$ and more than $300 \mathrm{~mm}$ thick, it was determined that more sensors should be placed between $1.4 \mathrm{~m}$ and $2.5 \mathrm{~m}$. If the estimated foundation reaction modulus is less than $50 \mathrm{MPa} / \mathrm{m}$ for a slab thickness greater than 450 $\mathrm{mm}$, deflections should be measured at distances greater than $2.5 \mathrm{~m}$.

\section{REFERENCES}

1)Lytton, R.L.: Backcalculation of pavement layer properties, nondestructive testing of pavements and backcalculation of moduli, STP 1026, ASTM, 1989.

2)Foxworthy, P.T. and Darter, M.I.: ILLI-SLAB and FWD deflection basin for characterization of rigid pavements, nondestructive testing of pavements and backcalculation of moduli, STP 1026, ASTM, 1989.

3) Strategic highway research program: Sharp' s layer moduli backcalculation procedure, SHRP-P-655, National research council, 1993.

\section{不変たわみ量に基づくコンクリート舗装の変形係数 \\ 棌 立軍・八谷好高・姚 祖康}

舗装表面でのたわみから舗装構成層の弾性係数を逆解析する場合にはコンピュー夕を用いる方法が多用 されている.コンクリート舗装の場合の解析精度を向上させるために, 不変たわみ量に基づく方法が開発 された。このたわみ量はコンクリート版の弾性保数に依存しないものであるから, 路床支持力係数, さら にはコンクリート版の弾性係数も唯一解として得られる.

この方法は，供用中の空港コンクリート舖装の構造評価に使用され，結果としてその有用性が確認され た. 